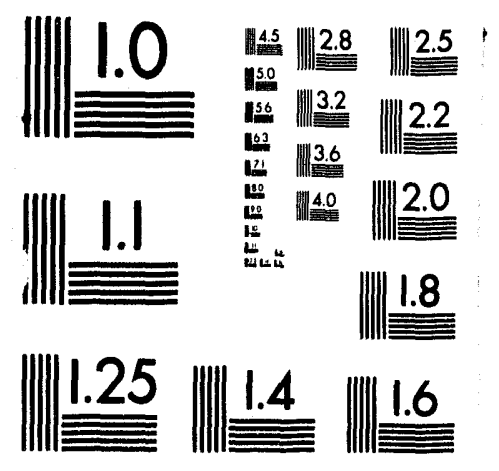



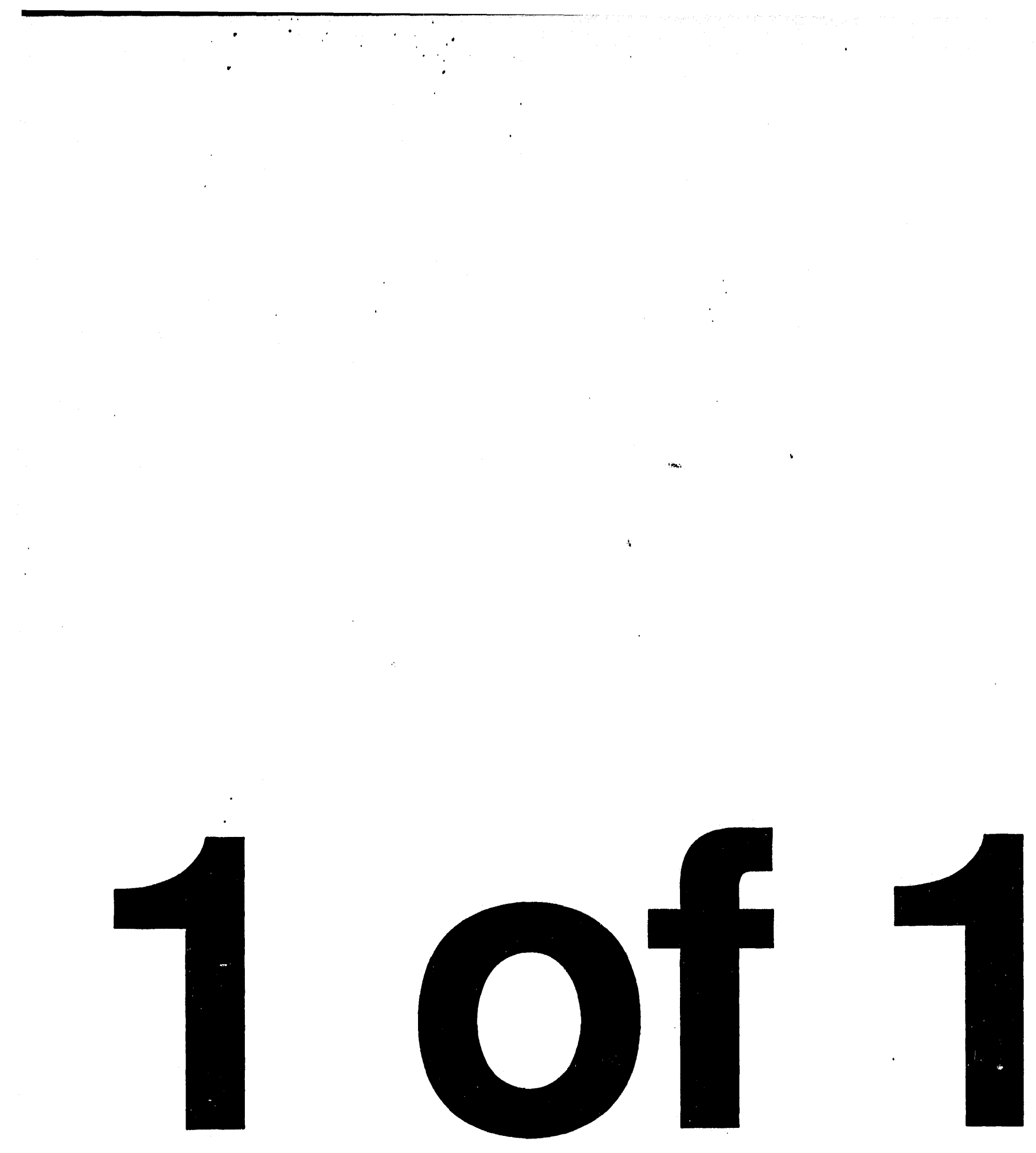
DOE/MC/29227-3538

(DE94000064)

\title{
A Model of the Capital Cost of a Natural Gas-Fired Fuel Cell-Based Utilities Plant
}

\author{
Topical Report
}

June 1993

Work Performed Under Contract No.: DE-FC21-92MC29227

\author{
For \\ U.S. Department of Energy \\ Office of Fossil Energy \\ Morgantown Energy Technology Center \\ Morgantown, West Virginia \\ By \\ The Southern California Gas Compqany \\ Research Department \\ Los Angeles, California
}




\section{DISCLAIMER}

This report was prepared as an account of work sponsored by an agency of the United States Government. Neither the United States Government nor any agency thereof, nor any of their employees, makes any warranty, express or implied, or assumes any legal liability or responsibility for the accuracy, completeness, or usefulness of any information, apparatus, product, or process disclosed, or represents that its use would not infringe privately owned rights. Reference herein to any specific commercial product, process, or service by trade name, trademark, manufacturer, or otherwise does not necessarily constitute or imply its endorsement, recommendation, or favoring by the United States Government or any agency thereof. The views and opinions of authors expressed herein do not necessarily state or reflect those of the United States Government or any agency thereof.

This report has been reproduced directly from the best available copy.

Available to $\mathrm{DOE}$ and $\mathrm{DOE}$ contractors from the Office of Scientific and Technical Information, 175 Oak Ridge Turnpike, Oak Ridge, TN 37831; prices available at $(615) 576-8401$.

Available to the public from the National Technical Information Service, U.S. Department of Commerce, 5285 Port Royal Road, Springfield, VA 22161; phone onders accepted at (703) 487-4650. 


\title{
A Model of the Capital Cost of a Natural Gas-Fired Fuel Cell-Based Utilities Plant
}

\author{
Topical Report
}

Work Performed Under Contract No.: DE-FC21-92MC29227

\author{
For \\ U.S. Department of Energy \\ Office of Fossil Energy \\ Morgantown Energy Technology Center \\ P.O. Box 880 \\ Morgantown, West Virginia 26507-0880
By
The Southern California Gas Compqany
Research Department
P.O. Box 3249
Los Angeles, California 90051-1249

June 1993 


\section{ABSTRACT}

The "Capital Cost Model" is the fifth topical report of the program for an "Economic Feasibility Analysis of Distributed Electric Power Generation Based Upon the Natural Gas-Fired Fuel Cell." This model defines the methods used in the Economic Analysis to estimate the cost associated with acquisition and installation of the capital equipment of the fuel cell systems defined by the central utility plant model.

The capital cost model estimates the cost of acquiring and installing the fuel cell unit, and all auxiliary equipment such as a boiler, air conditioning, hot water storage, and pumps. The model provides a means to adjust the initial cost estimates to consider learning associated with the projected level of production and installation of fuel cell systems. The capital cost estimate is an input to the cost of ownership analysis where it is combined with the operating cost and revenue model estimates.

Keywords: Capital Cost, Installation, Fuel Cell, Economic Analysis, Thermal Energy Distribution, Distributed Power Generation, Feasibility Analysis, Central Plant Configuration 


\section{FOREWORD}

his report was prepared under cooperative agreement No. DE-FC21-92MC29227, among the US Department of Energy, Fossil Energy, Morgantown Energy Technology Center, The Southern California Gas Company, The Brooklyn Union Gas Company and the Manes Associates, Incorporated. The participants are sponsoring an investigation by the Manes Associates, of the "Economic Feasibility of Distributed Electric Power Generation Based Upon the Natural Gas-Fired Fuel Cell."

This report, A Model for Estimating the Capital Cost of a Natural Gas-Fired Fuel Cell, is the fifth deliverable report of the contract. It is submitted in accord with Attachment B, Paragraph B of the "Financial Assistance Reporting Requirements Checklist." 


\section{TABLE OF CONTENTS}

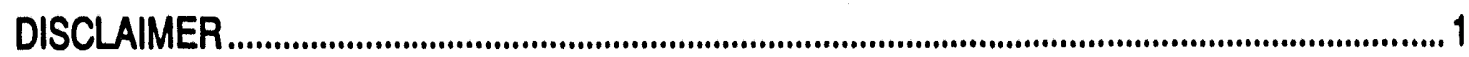

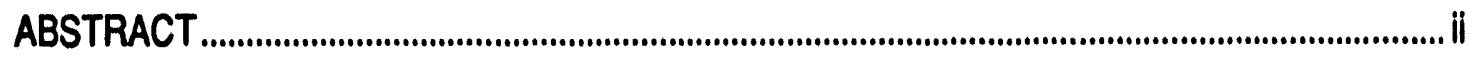

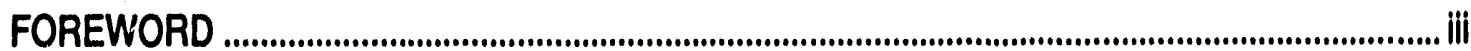

TABLE OF CONTENTS …................................................................................................... iv

LIST OF TABLES AND FIGURES ..................................................................................................... iv

EXECUTIVE SUMMARY ....................................................................................................

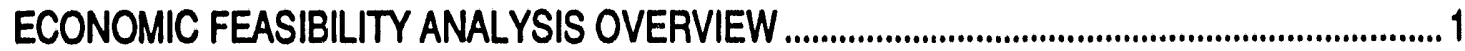

Combined Use Energy Survey........................................................................................ 1

Thermal Energy Distribution System Model .........................................................................2

Ownership Scenarios ....................................................................................................

Operations Model.....................................................................................................

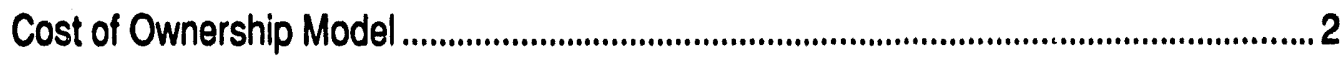

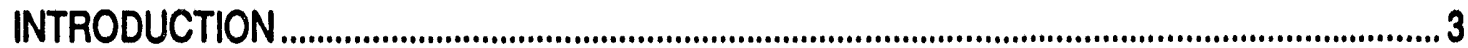

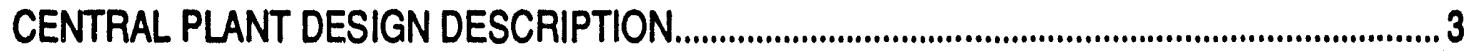

Item 1. Fuel Cell ..................................................................................................... 4

Item 2. Water Storage Tank........................................................................................... 4

tem 3. Absorption Chiller.......................................................................................... 4

Item 4. Heat Transfer Loop..............................................................................5

Item 5. Auxiliary Boiler ......................................................................................

Item 6. Cooling Tower ............................................................................................. 5

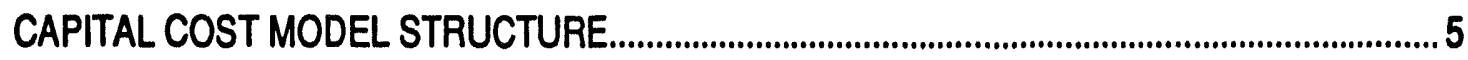

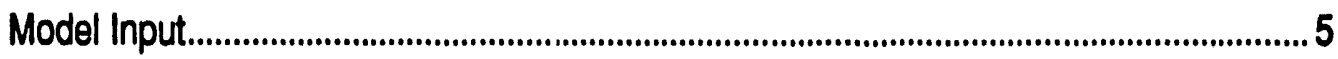

Cosi Model Equations............................................................................................................

Capital Equipment........................................................................................................................

Acquisition Cost.................................................................................................... .

Site and Installation Cost ................................................................................. 8

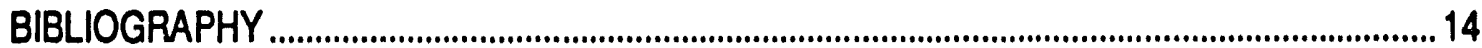

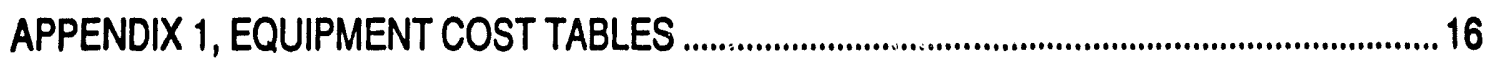

APPENDIX 2, LIST OF MODEL VARIABLE NAMES ….......................................................22 


\section{LIST OF TABLES AND FIGURES}

Table No. 1, Capital Cost Model Input Sheet........................................................ 6

Table No. 2, Capital Cost Model Output Sheet....................................................... 13

Figure No. 1, Elements of An Economic Feasibility Analysis of Fuel Cell-Based

Power Generation .............................................................................................. 1

Figure No. 2., Utility Plant Capital Cost Model Elements ...................................... 3 


\section{EXECUTIVE SUMMARY}

This report presents methods for estimating the capital cost of the several types of central utility plant systems configurations described in the Central Uitility PlantModel Report.

The capital cost model :

- estimates capital cost associated with the design capacity of the fuel cell defined by the central utility plant model,

- estimates the installation and start-up costs associated with the design capacity of the fuel cell defined by the central utility plant model,

- adjusts the estimated cost to allow for industry improvement in production and installation costs as the number of fuel cell applications increase,and

- provides a total capital cost value for each equipment scenario specified in the cost of ownership model. 


\section{ECONOMIC FEASIBILITY ANALYSIS OVERVIEW}

This report describes the Capital Cost Model of the fuel cell and ancillary elements of the central utility plant. The cost of ancillary equipment is forecast by scaling cost data from the R. S. Means Co.'s "Means Mechanical Cost Data, 1992" with a series of relationships developed by multiple linear regression. The capacity or size of each element of the utility plant varies as a dependent variable of demand profile and user specified space conditioning loads. The capital cost of the fuel cell varies with a manufacturing learning expression. The initial value of fuel cell cost ( the starting point on the learning curve) is an important parameters of the feasibility analysis.

The "Economic Feasibility Analysis of Distributed Electric Power Generation Based upon the Natural GasFired Fuel Cell" is comprised of a survey of energy users, the development of numeric models of an energy distribution system and a central plant utilities system that includes a fuel cell. A model of the capital cost of the hardware elements is combined with a series of ownership scenarios and an operations model that provide the necessary input for a model of the cost of ownership of a fuel cell-based power generation system. The relationship among these elements of the project is represented by Figure No. 1.

Figure No. 1, Elements of An Economic Feasibility Analysis of Fuel Cell-Based Power Generation

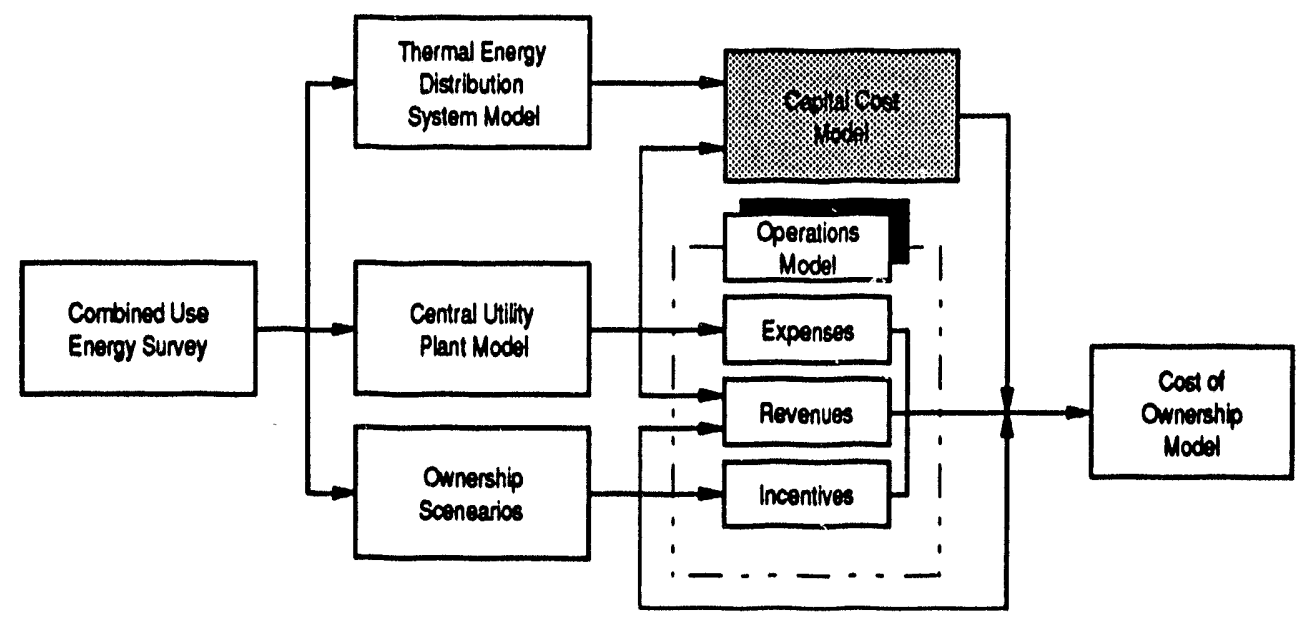

\section{Combined Use Energy Survey}

A survey of the extensive literature on energy consumption among a variety of user classes was conducted. It established the consumption rates and the relationship between consumption of thermal and electrical energy. The literature survey was supplemented with data on consumption history contributed by 15 industrial energy users in the Southern California area. The data fell into categories of demand profiles by industry and end-use that were non-dimensionalized by peak use. The profiles were used to model the demand on the fuel cell-based utility plant. 
Central Plant Utility Model

The central plant model sizes a fuel cell for one of several user-chosen electrical demand profiles. The thermal energy produced is a dependent variable of the electric energy computed by a model of fuel cell performance and gas consumption. The model computes the thermal energy required for space conditioning and other uses to size an absorption chiller, boiler, thermal accumulator tank and system pumps.

\section{Thermal Energy Distribution System Model}

The report describes several types of thermal energy distribution systems that are suitable ior the distribution of thermal energy to multiple points of use. The primary conclusion drawn from the work is that a four-pipe, hydronic distribution system is most suitable for adaptation of the fuel cell based central plant. The report on the model is complete and was submitted under separate cover.

\section{Ownership Scenarios}

The treatment of revenues, expenses and incentives are dependent on the owners contractual and regulatory status with respect to the utility companies in the service area and the owner's customers for the energy produced by the fuel cell. The capital recovery period and the requisite return on investment will also vary by the class of owner, their industry and regulation.

\section{Operations Model}

The business operations model computes fuel cell operating expenses based upon gas price forecasts or an input parameter. The maintenance expenses include periodic fuel cell stack refurbishment and the purchase of back-up electric power and additional space heating boiler fuel while the cell is out of service.

The revenue stream is imputed from the avoided cost of purchasing electric and thermal energy at rates appropriate to the ownership class, time of day and season. The power and thermal energy production rates are computed by the Central Utility Plant Model. An additional revenue stream is derived from investment credit, utility displacement credits or RECLAIM' permit sales. In some cases the enabling legislation to support these incentives does not yet exist. Provisions have been included in the operations model to enable the prospective owner to account for this important source of revenue and public good-will.

\section{Cost of Ownership Model}

A model of the cost of fuel cell ownership is the final product of the series of models represented in Figure No. 1. The model combines the product of the capital cost model, ownership scenarios and the operations model cash flows to compute the cost of ownership. The form of the output is user selectable from a menu that inciudes cash flow curves, net present value as a function of capital cost and fuel cost or the internal rate of return on investment. The variety of output forms has been chosen to accommodate the expected interests of the variety of industries that will evaluate the Economic Feasibility of Distributed Electric Power Generation Based on the Natural Gas-Fired Fuel Cell.

${ }^{1}$ RECLAIM is the recently announced program of the South Coast Air Quality Management District to create a trading market for emission permits. The emissions of a fuel cell is below the most stringent limits proposed for the year 2010. A fuel cell owner should be able to sell all of their annual permit allowances on the open market. Similar programs have already been established at the federal level and will likely be emulated in other non-compliant areas of the country. 


\section{INTRODUCTION}

Fuel cell capital costs are a function of the fuel cell size and systems capacity. The fuel cell size and capacity are selected when the Central Utility Plant configuration is selected. The Capital Cost Model estimates the acquisition and installation costs associated with the size and configuration of the selected Central Utilly Plant confilguration.

\section{CENTRAL PLANT DESIGN DESCRIPTION}

The design of a fuel cell-based central utlity plant is similar to a conventional plant design. Both systems are designed to deliver hot and chilled water to a hydronic, four pipe thermal distribution system. Figure No. 3 is a a schematic of the fuel cell-based plant represented by this model of capital costs.

The important features of the plant design considered include 1.) the fuel cell 2.) a large hot water storage tank 3.) a gas-fired absorption chiller for air conditioning and 4.) an additional heat transfer loop to supply hot water or steam to the chiller. 5.) An auxillary boiler to supply additional thermal capacity beyond the capacity of the fuel cell or serve as a back-up supply for space heat in the event of an unplanned fuel cell outage. 6.) plant cooling Tower. The principle of plant operation and the basis for the model of capital costs described in the following paragraphs are keyed to the ltem numbers shown on Figure No. 3. Other items of plant equipment that are not unique to the fuel cell system are not numbered on the schematic or represented in the model.

Figure No. 3., Utility Plant Capital Cost Model Elements

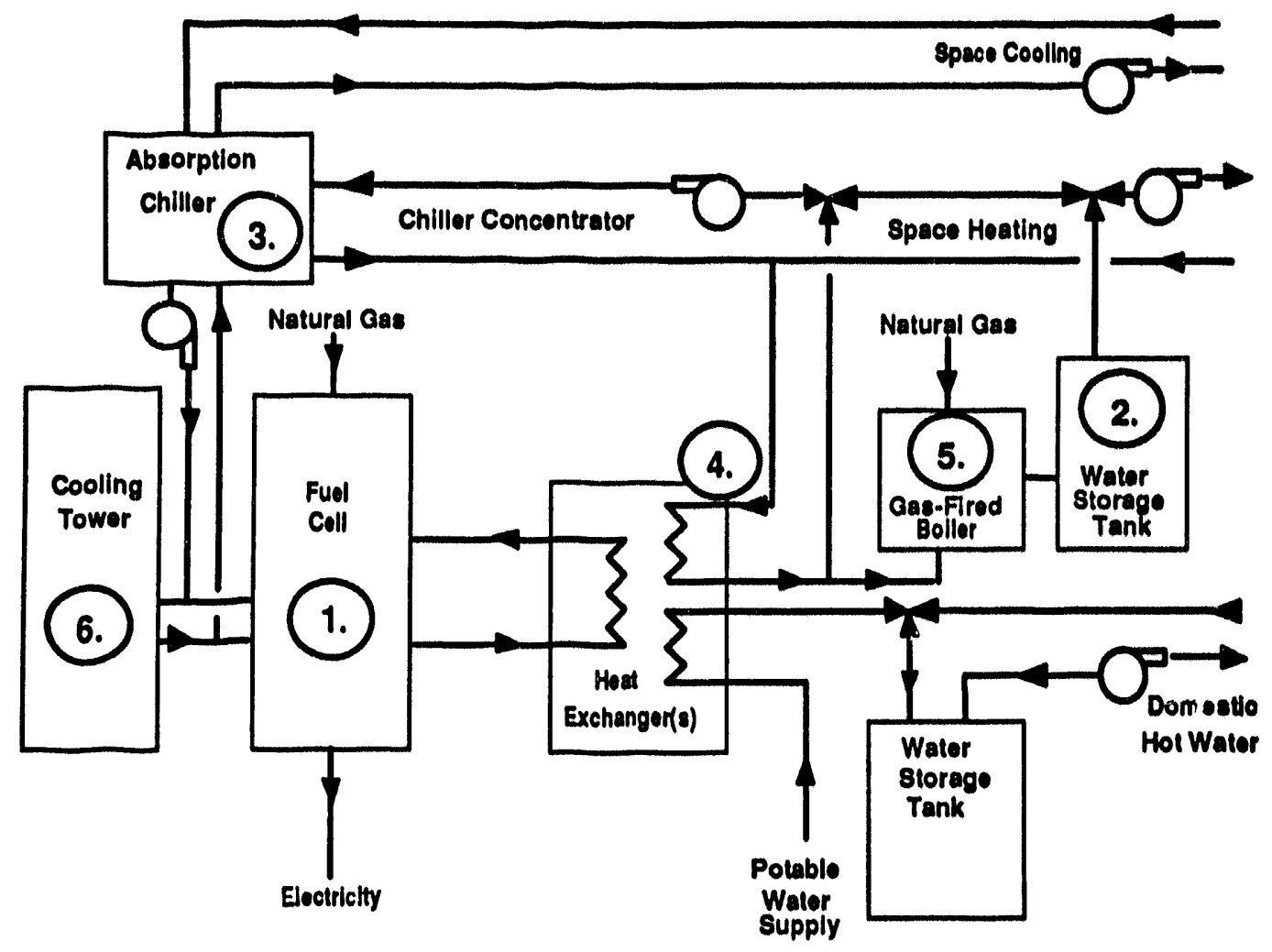




\section{nem 1. Fual Coll}

There are several different fuel cell technologies 2 now in hardware development or entering the early stage of commercialization. The principle of operation is the same for each type of fuel cell. A natural or oynthetic gaseous fuel comprised mainly of methane is reformed over a catalyst with high temperature steam to produce hydrogen and carbon monoxide. The carbon monoxide is further reacted with steam to produce addltional hydrogen and carbon dioxide. The hydrogen is reacted with oxygen from the air in an electrolyte to produce an electron flow, hot water or steam and carbon dioxide. The principle of opsration of each type of cell is the same. They differ only in electrolyte material and operating conditions.

The fuel cell streams that are represented in the operations model are fueled by natural gas and produce electicity and thermal energy in the form of hot water. Cooling water is also supplied to the fuel cell under abnormal operations. The value of the cooling stream is not modeled other than to provide for back-up electricly connections charges and the purchase of stand-by energy for space heating by the operations model

\section{Mom 2. Water Storage Tank}

The tuel cell-based central utility plant design includes two water storage tanks. The potable water system provides hot water for cooking and sanitation and a second tank acts as a "thermal accumulator" for the system. The accumulator is used to smooth thermal demand peaks in residential applications. In these applications there are large surges in thermal energy (hot water) demand for bathing and cooking early in the morning and late in the evening. The tank should store the difference between the average and the peak thermal energy consumption. The average to peak ratio for residential applications is about 0.7 .

\section{Hem 3. Absorption Chiller}

The economic viability of the fuel cell is dependent upon productive use of the thermal energy produced by the power plant. The potential fuel cell owner should exploit the availability of the "free" thermal energy in the design of the central utility plant. The equipment in the analysis of the fuel cell-based central utility plant design includes absorption cooling for larger applications. A $200 \mathrm{~kW}$ phosphoric acid fuel cell produces $850,000 \mathrm{Btu} / \mathrm{hr}$ in the form of hot $\left(\sim 75^{\circ} \mathrm{C}\right)$ water. This will supply $70 \%$ of the energy required to power a 100 Ton absorption chiller.

\footnotetext{
2There are three types of fuel cells being considered for stationary power generating applications. The fuel cell types are designated by the electrolyte that is used for the electrochemical reaction that produces electric power and hot water or steam. The phosphoric acid electrolyte cell was recently introduced to commercial markets by ONSI Corp. A fuel cell that uses molten carbonate salts as an electrolyte is in development by a consortium, MC-Power. The first pilot plant application of this bechnology is under construction in the PG\&E service area. The more advanced solid oxide electrolyte cell is being developed by several firms in the United States and Japan under the sponsorship of commercial interests, the Department of Energy and public utilities.
} 


\section{Item 4. Heat Transfer Loop}

An extra heat transfer loop transfers energy from the fuel cell hot water output and supplies the heated water to pre heat the boiler feed water. The loop is comprised of a heat exchanger and a number of circulating pumps. The fuel cell output temperature is too low to "fire" absorption chiller and must be boosted by the boiler. The model computes the value of the thermal energy as the cost of a quantity of natural gas to raise water to the same temperature. It also amortizes the cost of a suitable boiler over the life of the plant.

\section{Hem 5. Auxiliary Boiler}

The fuel cell is used as a boiler preheater, as reflected in Figure No 3 . The boiler is sized to deliver all of the thermal energy required by the application, including that normally supplied by the fuel cell. This redundancy is important in colder climates where there are health and safety issues associated with the loss of space heat (due to an unplanned outage of the fuel cell). The boiler is also used to raise the $75^{\circ} \mathrm{C}$ fuel cell exit temperature to the level required in the absorption chiller concentrator loop. In very large cooling applications (over 400 tons) the fuel cell output could be used as the first stage in a multi stage absorption chiller. Later fuel cell technologies will not require the temperature boost for absorber operation.

\section{Item 6. Cooling Tower}

The cooling tower would not normally be considered unique to a fuel cell based central utilities plant installation. It is included in the model as a substitute for a coolant to air heat exchanger used in current installations. It is used to allow full electrical power production with installations that do not use the thermal energy produced by the fuel cell.

\section{CAPITAL COST MODEL STRUCTURE}

The capital cost model uses the systems capacity parameters defined in the Central Utility Plant model to estimate the cost of acquiring and installing the fuel cell system. The procurement cost for the hardware are estimated based upon the size of the system and the number of systems in use. for the balance of plant equipment, the per unit cost is estimated by multiplying the capacity of the unit by a cost factor. The cost factor is a linear regression of the capacity of each hardware element and the published cost of the unit in 1992 dollars. The detail data and the results of the multiple linear regression computation are included in Appendix 1.

\section{Model Input}

The model is directly linked to the Central Utility Plant Model for input. The user is also given the option of direct input to the model. Table No. 1 is a reproduction of the model input sheet. 
Table No. 1, Capital Cost Model Input Sheet

\begin{tabular}{|c|c|c|}
\hline $\begin{array}{c}\text { Contral Utility Plant Capital Cost Model } \\
\text { Usor Input Paramolers }\end{array}$ & $\begin{array}{l}\text { Parameter } \\
\text { Name }\end{array}$ & $\begin{array}{l}\text { Parameter } \\
\text { Value }\end{array}$ \\
\hline \multicolumn{3}{|l|}{ Fuel Coll } \\
\hline 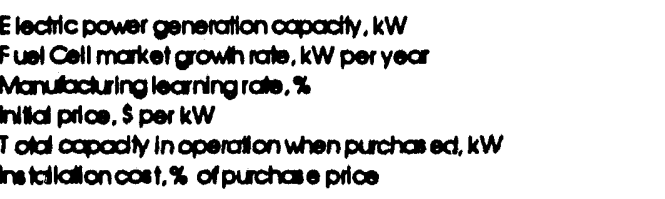 & $\begin{array}{l}320 \\
\text { Gowh_Rote } \\
\text { Lecoming } \\
\text { First_Pition } \\
\text { Population } \\
\text { ristallation }\end{array}$ & $\begin{array}{r}320 \\
133,333 \\
96 \\
2500 \\
2000 \\
10 x\end{array}$ \\
\hline Bollor & & \\
\hline 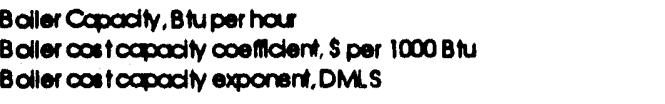 & $\begin{array}{l}\quad 750000 \\
\text { Boller_Coefidient } \\
\text { Boller_exponent }\end{array}$ & $\begin{array}{r}750000 \\
73.88 \\
0.72\end{array}$ \\
\hline Nit Condilioning & & \\
\hline 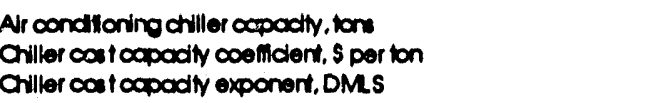 & $\begin{array}{l}\text { Air_Condiloning } \\
\text { Oriller_Coefindient } \\
\text { Ciller_Exponent }\end{array}$ & $\begin{array}{r}200 \\
2526 \\
0.7023\end{array}$ \\
\hline Hot W aler s lorage T ank & & \\
\hline 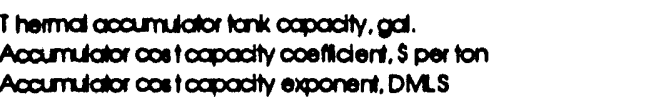 & $\begin{array}{l}\text { Volume } \\
\text { Acoumulator_Coomdent } \\
\text { Acoumulation_Exponent }\end{array}$ & $\begin{array}{r}1878 \\
252.8 \\
0.6694\end{array}$ \\
\hline Cooling T ower & & \\
\hline 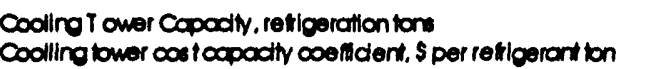 & $\begin{array}{l}\text { Coolina_tower_Capadiv } \\
\text { Tower_Coem dent }\end{array}$ & 400 \\
\hline systom P umps, mls collaneous har dware & & \\
\hline 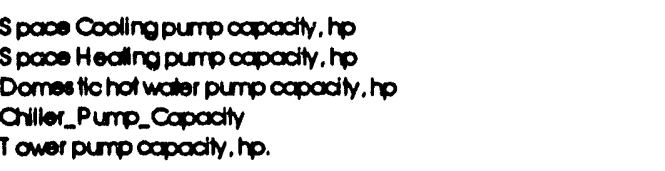 & 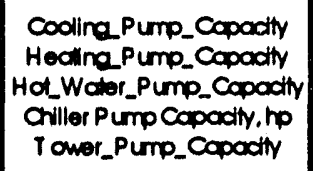 & $\begin{array}{l}3.23 \\
0.60 \\
0.16 \\
8.59 \\
4.19\end{array}$ \\
\hline 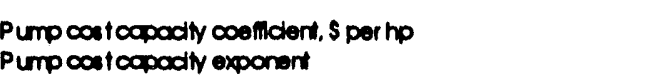 & $\begin{array}{l}\text { Pump_cost_coefidient } \\
\text { Pump_cost_Exponent }\end{array}$ & $\begin{array}{r}3097 \\
0.1803\end{array}$ \\
\hline
\end{tabular}

\section{Cost Model Equations}

The capital cost model uses the results of the Central Utility Plant Model that defines the elements of the plant and their capacity. In addition, the model requires an estimate of size of the fuel cell market. This is used to predict the appropriate position on the manufacturing learning curve for both the fuel cell unit and the installation cost.

\section{Capital Equipment}

The cost of the central utility plant configuration of the fuel cell system is comprised of fixed capital equipment, installation and start-up. ${ }^{3}$ The capital equipment of the fuel cell central utility plant include

${ }^{3}$ All costs assoicated with replacing capital equipment, such as the fuel cell stack, are a function of the predicted operating profile of the fuel cell. Therefoe, the costs associated with replacing the fuel cell stack are included in maintenance portion of the Operations Model. 
(1) the fuel cell plant, including the cell stack 4 ,

and

(2) the balance of plant equipment associated with the plant system.

\section{Acquisition Cost}

Acquisition Cost for the primary capital equipment is estimated by summing the estimated cost of the capital equipment defined by the Central Utility Plant Model along with use taxes and the cost of trarisportation to the fuel cell site. The installation costs are also included with each item of capital equipment as described on Page 8 , following.

C_Plant $=C_{F C}+C_{B}+C_{A C}+C_{T A}+C_{C T}+C_{M E}+T+T X$

Where:

C_Plant $=$ Central Plant Acquisition Capital Equipment Cost

$C_{F C}=$ Fual Cell Cost+ Fuel Cell Installation Cost

$C_{B}=$ Boiler Cost + Boiler Installation Costs

$C_{A C}=$ Air Conditioning Unit ( $s$ ) Cost + Air Conditioning Installation Cost

$C_{T A}=$ Thermal Accumulator Equipment Cost + Thermal Accumulator Installation Cost

$C_{C T}=$ Cooling Tower Cost + Cooling Tower Installation Cost

$C_{M E}=$ Miscellaneous Equipment Cost + Miscellaneous Equipment Installation Cost

$T=$ Transportation Costs

$T_{x}=$ Use Taxes

The model estimates the equipment cost as a function of the capacity, output or size of each type of equipment. The general expression for each cost estimating relations is:

\section{$\mathbf{C x}_{\mathrm{x}}=$ Capacity $\times$ Cost Factor}

Where:

$$
C x=\text { the capital cost of equipment } X
$$

4 Currently the phosphoric Acid fuel cell capital cost is approximately $\$ 2,500$ per killowatt. 
Capacity = The performance capacity of the equipment, i.e cooling capacity of an air conditioning unit is expressed in tons.

Cost Factor $=$ The estimating relationship factor developed for the equipment item from historical and industry data sources. The factor is a least squares regression fit of per unit cost to the capacity unit term related to the equipment item.

The expression and coefficients for each type of equipment are derived by correlating the per unit cost to the equipment capacities or output. The per unit costs includes acquisition costs, use taxes, transportation, site engineering, ancilliary equipment, installation labor, and the necesary building and operation permits and fees. This approach should not affect the conclusions drawn from the model results since each of the elements of equipment cost are proportional to capacity or fuei cell acquisition cost and the fuel cell cost is treated as a parameter rather than a dependant variable.

\section{Site and Installation Cost}

The elements of the site and installation costs that were included in developing the equations for each item of capital equipment are engineering, permitting, construction and startup costs. The model equations for learning were developed from data from 10 recent installations Southern California. The elements of cost were combined into a single value for acquisition that included all of the costs that are proportional to acquisition cost.

$$
C_{1}=C_{E}+C_{P}+C_{C o n}+C_{S / T}
$$

Where:

$$
\begin{aligned}
& C_{1}=\text { Installation Cost for the Fuel Ceil System } \\
& C_{E}=\text { Cost of Engineering } \\
& C_{P}=\text { Cost of Permits and Licenses } \\
& C_{C \text { n }}=\text { Cost of Construction } \\
& C_{S / T}=\text { Cost of start-up and initial systems tests }
\end{aligned}
$$


Engineering $\operatorname{Cost}\left(C_{E}\right)$.- The model estimates the cost of engineering to be approximately 5 percent of the original equipment cost. This is consistent with the experience on the first ten units installed in southern California during 1992 and 1993.

Permits and Licenses $\left(C_{p}\right)$. The submission of applications to the permitting authority, support during the permitting process and payment of the appropriate fees are estimated to be approximately 1 percent of the fuel cell cost.

Construction $\left(C_{C o n}\right)=$ Construction of the fuel cell site including all utilities, foundations and electrical power connections are estimated to be 25 percent of the fuel cell cost.

The results of a sample calculation of the capital costs of a fuel cell based central utility plant are presented in Table No. 2.

Fuel Cell Unit Cost $\left(C_{F C}\right)$ -

$C_{10}=\left(E_{10} \times C_{k W}\right) /(N)^{(2-L O Q(L)) / L O Q(M)}$

Where

$\mathrm{C}_{\mathrm{FC}}=$ Cost of the fuel cell

$E_{F C}=$ Fuel Cell electrical capacity in $\mathrm{kW}$

$C_{k W}=$ Cost of the fuel cell per $\mathrm{kW}$ of electric capacity in $\$ / \mathrm{kW}$

$U_{F C}=$ Unit price of the fuel cell unit after having produced $M$ units

$\mathrm{N}=$ Number of fuel cell units produced at the time of the installation

$M=\quad$ Number of fuel cell units produced at the time the cost $C_{k W}$ was evaluated

$L=$ the assumed learning curve slope

Auxiliary Equipment Cost (Balance of Plant)

Virtually all of the balance of plant equipment may vary in size depending upon the energy consumption characteristics of the given user. The equipment with the greatest variability in size (and cost) will be the boilers, chillers, storage tanks, and cooling towers. Piping, pumps, controls, and heat exchangers there will be much less variability in size and cost, depending on the individual user. 
Boiler $\left(C_{B}\right)$.

$$
C_{b}=73.87 \times(0 / 1000)^{.7163}
$$

Where:

$C_{B}=$ Cost of the boiler in the central utility plant configuration

$0=$ Boiler capacity in Btu / hr 
Air Conditioning $\left(C_{A C}\right)$

$$
C_{\infty}=2526 \times\left(A C_{1}\right)^{7083}
$$

Where:

$$
A C_{T}=\text { Air Conditioning Chiller Capacity in tons }
$$

Thermal Accumulator Tank $\left(C_{T A}\right)$

$C C_{t}=109.84 \times\left(T_{h w}\right)^{.6094}$

Where:

$T_{H W}$ = Thermal Accumulator Tank Capacity in gallons

\section{Cooling Tower $\left(C_{C T}\right)$}

$$
C_{\alpha t}=72.00 \times C T_{1}
$$

Where:

$$
C T_{T}=\text { Cooling tower cooling capacity in tons of refrigeration }
$$

\section{Miscellaneous Hardware $\left(C_{M E}\right)$}

Air Conditioning Loop Pump

$$
C_{\text {eac }}=3108 \times\left(P_{\text {eac }}\right)^{.1431}
$$


Space Conditioning Loop Pump

$$
C_{\text {eac }}=3108 \times\left(P_{\text {sec }}\right)^{.1431}
$$

Domestic Hot Water Loop Pump

$$
C_{\text {ahw }}=3108 \times\left(P_{\text {shw }}\right)^{1431}
$$

Cooling Tower Water Loop Pump

$$
C_{\text {atw }}=3108 \times\left(P_{\text {stw }}\right)^{.1431}
$$


Table No. 2, Capltal Cost Model Output Sheet

\begin{tabular}{|c|c|c|}
\hline $\begin{array}{l}\text { CENTRAL UTLITY PLANT SYSTEM } \\
\text { CAPITAL COST MODEL }\end{array}$ & $\begin{array}{l}\text { Parameter } \\
\text { Name }\end{array}$ & $\begin{array}{l}\text { Parameter } \\
\text { Value }\end{array}$ \\
\hline \multicolumn{3}{|l|}{ Fuel Coll } \\
\hline $\begin{array}{l}\text { Fuel Call Electrical Capacth, kW } \\
\text { Fuel Cell Cost. } \$ \text { per kW } \\
\text { Fuel Cell Capltal Cost }\end{array}$ & $\begin{array}{c}320 \\
\text { Cell_Cost_Rate } \\
\text { Cel__Cost }\end{array}$ & $\begin{array}{r}320 \\
\$ 2,111 \\
\$ 675,390\end{array}$ \\
\hline Boller & & \\
\hline Boller Capltal Cost, $\mathbf{S}$ & Boller_Cost & $\$ 8,415$ \\
\hline Alt Conditloning & & \\
\hline Spoce Cooling Absorption Chiller Cost & Chiller_Cost & 5107.726 \\
\hline Hot Water Storage Tank & & \\
\hline Thermal Accumulator Tank Cost. \$ & Accumulator_Cost & $\$ 39275$ \\
\hline Coollng Tower & & \\
\hline Cooling Tower Cost. \$ & Tower_Cost & $\$ 28,800$ \\
\hline Mlicellanoous Equipment & & \\
\hline $\begin{array}{l}\text { Air Conditioning Loop Pump Cost. S } \\
\text { space Conditioning Loop Pump Cost. \$ } \\
\text { Domestic Hot Water Loop Pump Cost. S } \\
\text { Concentrator Loop Pump Cost. \$ } \\
\text { Cooling Tower Water Loop Pump Cost. S }\end{array}$ & $\begin{array}{l}\text { Coolina_Pump_Cost } \\
\text { Heating_Pump_Cost } \\
\text { Water_Pump_Cost } \\
\text { Concentrator_Pump_Cost } \\
\text { Tower_Pump_Cost }\end{array}$ & $\begin{array}{l}\$ 3.694 \\
\$ 2.865 \\
\$ 2.352 \\
\$ 4.012 \\
\$ 3.842\end{array}$ \\
\hline Total Miscellaneous Equipment Costs, \$ & Mlscellaneous_Equipment & $\$ 16.765$ \\
\hline $\begin{array}{l}\text { CENTRAL UTILIT PLANT } \\
\text { CAPITAL COST SUMMARY }\end{array}$ & & \\
\hline $\begin{array}{l}\text { Fuel Cell Capltal Cost } \\
\text { Boller Capltal Cost, } \$ \\
\text { Space Coollng Absorption Chiller Cost } \\
\text { Thermal Accumulator Tank Cost, \$ } \\
\text { Cooling Tower Cost. \$ } \\
\text { Total Miscellaneous Equlpment Costs, \$ }\end{array}$ & $\begin{array}{c}\text { Cell_Cost } \\
\text { Boiler_Cost } \\
\text { Chiller_Cost } \\
\text { Accumulator_Cost } \\
\text { Tower_Cost } \\
\text { Miscellaneous_Equlpment }\end{array}$ & $\begin{array}{r}\$ 676.390 \\
\$ 8.415 \\
\$ 107.726 \\
\$ 39.275 \\
\$ 28.800 \\
\$ 16.765\end{array}$ \\
\hline Central Utilty Plant Capltal Cost. \$ & Plant_Capltal_Cost & $\$ 876,371$ \\
\hline $\begin{array}{l}\text { Trial Capltal Cost Component of } \$ / \mathrm{kW}^{\prime \prime} \mathrm{hr} \\
\text { Fuel Cell Refurblshment }\end{array}$ & & $\begin{array}{l}0.0027 \\
0.0241\end{array}$ \\
\hline
\end{tabular}




\section{BIBLIOGRAPHY}

1. ASHRAE, ASHRAE Handbook: Equipment 1988, Chapters 13, 23.

2. ASHRAE, ASHRAE Handbook: Systems 1984, Chapters 5,13.

3. GRI, Comparative Market and Economic Analyses: Onsite Fuel Cells, Final Report Vol. I, Dec. 1980, GRI-79/0095.

4. GRI, Comparative Market and Economic Analyses: Onsite Fuel Cells, Final Report Vol. IIAppendices, Dec. 1980, GRI-79/0095.2.

5. GRI, 481 Prototypical Commercial Buildings for Twenty Urban Market Areas, Dec. 1990, GRI-90/0326

6. International Fuel Cells, The PC-25 Fuel Cell Power Plant, Aug. 1986.

7. S. Means Co. Inc., Means Facilities Cost Data 1993 Construction Consultants \& Publishers, Kingston, MA 1993

8. S. Means Co. Inc., Means Mechanical Cost Data 1992, Construction Consultants \& Publishers, Kingston, MA 1992.

9. Stamper \& Koral, Handbook of air-conditioning, Heating and Ventilating, Chapters 7.

10. GRI, Commercial Buildings Cogeneration Market: Characterization and Trends, April 1990 GRI-89/0246

11. GRI, 40-kW Onsite Fuel Cell Field Test Summary Utilities Activities Report - Final Report, July 1987, GRI-87/0205 
13. The Trane Company, Commercial Systems Group Product Information Literature, Single Stage Absorption Cold Generator: 101 to 1660 Tons, La Crosse, WI, March 1989

14. Manes Associates, Combined Use Energy Survey, Published under contract DE-FC92MC29227,as part of An Economic Feasibility Analysis of Distributed Electric Power Generation Based Upon the Natural Gas-Fired Fuel Cell, November 1992

15. Manes Associates, A Central Plant Utility Model, Published under contract DE-FC92-MC29227 as part of An Economic Feasibility Analysis of Distributed Electric Power Generation Based Upon the Natural Gas-Fired Fuel Cell, November 1992

16. Energy Information Administration, U.S. Department of Energy, Annual Energy Outlook 1993 DOE/EIA-0383 (93), January 1993 


\section{APPENDIX 1, EQUIPMENT COST TABLES}

The following is a list of the equipment discussed previously along with their associated costs broken down by the size or type of the equipment: 5

Material costis the actual bare material cost as gathered from manufacturers, dealers, and distributors it does not include sales tax.

Labor costs are based on the type of crew necessary, the average productivity, and the hours necessary.

Equipment costs are the rental and operating \& maintenance costs for equipment necessary for installation of the item of interest.

Total costs including overhead and profit represents the initial costs plus $10 \%$ of the material and equipment costs, and $10-18 \%$ of the labor costs (depending on the type of crew necessary).

5 The primary source for this information is from construction/ engineering cost estimating guides such as Means Mechanical Cost Data 1992, and Means Facilities Cost Data 1987. 
Absorption Chiller Cost

\begin{tabular}{rrrrrrr}
$\begin{array}{c}\text { Capacity } \\
\text { Tons }\end{array}$ & \multicolumn{1}{c}{$\begin{array}{c}\text { Material } \\
\text { Cost, } \$\end{array}$} & $\begin{array}{c}\text { Installation } \\
\text { hours }\end{array}$ & $\begin{array}{c}\text { Installation } \\
\text { Cost @ } \$ 25 / \mathrm{hr}\end{array}$ & $\begin{array}{c}\text { Installed } \\
\text { Cost, \$ }\end{array}$ & $\begin{array}{c}\text { Mit Hand'g } \\
\text { Proflt, \$ }\end{array}$ & \multicolumn{1}{c}{$\begin{array}{c}\text { Total } \\
\text { Cost. \$ }\end{array}$} \\
101 & 50344 & 221 & 5519 & 55863 & 10553 & 66417 \\
200 & 81545 & 361 & 9028 & 90573 & 17183 & 107756 \\
230 & 90000 & 399 & 9985 & 99985 & 18985 & 118969 \\
288 & 105484 & 470 & 11740 & 117224 & 22289 & 139513 \\
336 & 117610 & 525 & 13119 & 130729 & 24880 & 155609 \\
432 & 140439 & 629 & 15723 & 156162 & 29767 & 185930 \\
480 & 151282 & 679 & 16963 & 168245 & 32091 & 200337 \\
768 & 210803 & 952 & 23799 & 234602 & 44879 & 279481 \\
960 & 246766 & 1118 & 27949 & 274715 & 52626 & 327341 \\
1056 & 263939 & 1197 & 29936 & 293875 & 56330 & 350205
\end{tabular}

\section{Absorption Chiller Costs}

\begin{tabular}{crrrr}
$X$ & \multicolumn{1}{c}{$Y$} & \multicolumn{1}{c}{$\log X$} & \multicolumn{1}{c}{$\log Y$} & \multicolumn{1}{c}{$Y$ Calc } \\
Capacity. tons & \multicolumn{1}{c}{$\begin{array}{c}\text { Costs, } \$ \\
\text { Log( Capacity) }\end{array}$} & $\log ($ Cost) & \multicolumn{1}{c}{ Cost, $\$$} \\
101 & 66,417 & 2.0043 & 4.8223 & 66,415 \\
200 & 107,756 & 2.3010 & 5.0324 & 107,756 \\
230 & 118,969 & 2.3617 & 5.0754 & 118,970 \\
288 & 139,513 & 2.4594 & 5.1446 & 139,514 \\
336 & 155,609 & 2.5263 & 5.1920 & 155,611 \\
432 & 185,930 & 2.6355 & 5.2693 & 185,931 \\
480 & 200,337 & 2.6812 & 5.3018 & 200,338 \\
768 & 279,481 & 2.8854 & 5.4464 & 279,480 \\
960 & 327,341 & 2.9823 & 5.5150 & 327,339 \\
1056 & 350,205 & 3.0237 & 5.5443 & 350,201 \\
& & 0.7083 & 3.4025 & 2526 \\
& & $3.9398 E-06$ & $1.026 E-05$ & \\
& & 1 & $3.81809 E \cdot 06$ & \\
& & $3.2325 E+10$ & 8 &
\end{tabular}




\section{Gas Fired Boiler Costs}

\begin{tabular}{ccrrrrr}
$\begin{array}{c}\text { Capacity } \\
\text { Btu X 1000 }\end{array}$ & $\begin{array}{c}\text { Material Cost } \\
\$\end{array}$ & $\begin{array}{c}\text { Installation } \\
\text { hours }\end{array}$ & $\begin{array}{r}\text { Installation } \\
\text { Cost @ } \$ 25\end{array}$ & $\begin{array}{c}\text { Installed } \\
\text { Cost, } \$\end{array}$ & $\begin{array}{c}\text { Mtl Hand'g } \\
\text { Profit }\end{array}$ & \multicolumn{1}{c}{$\begin{array}{c}\text { Total } \\
\text { Cost, } \$\end{array}$} \\
100 & 1,125 & 24 & 600 & 1,725 & 713 & 2,438 \\
203 & 1,760 & 32 & 810 & 2,570 & 986 & 3,556 \\
320 & 2,540 & 40 & 1,000 & 3,540 & 1,254 & 4,794 \\
440 & 3,310 & 49 & 1,250 & 4,560 & 1,581 & 6,141 \\
544 & 4,460 & 53 & 1,350 & 5,810 & 1,796 & 7,606 \\
765 & 5,770 & 58 & 1,475 & 7,245 & 2,052 & 9,297 \\
1088 & 7,610 & 64 & 1,625 & 9,235 & 2,386 & 11,621 \\
2000 & 13,200 & 84 & 2,125 & 15,325 & 3,445 & 18,770 \\
\hline 5520 & 37,750 & 228 & 5,775 & 43,525 & 9,550 & 53,075 \\
\hline
\end{tabular}

Last Data point not used for regression

Boiler Costs less last data point

\begin{tabular}{crrrr}
$\begin{array}{c}X \\
\text { Capacity, }\end{array}$ & \multicolumn{1}{c}{$Y$} & \multicolumn{1}{c}{$\log X$} \\
$\begin{array}{c}\text { Cost } \$ \\
1000 \text { Btu }\end{array}$ & $\begin{array}{c}\text { Log } \\
\text { Capacity }\end{array}$ & \multicolumn{1}{c}{$\begin{array}{l}\text { Log } \\
\text { Cost }\end{array}$} & $\begin{array}{c}\text { Ca;culated } \\
\text { Cost }\end{array}$ \\
100 & 2,150 & 2.0000 & 3.3324 & 1,991 \\
203 & 3,150 & 2.3075 & 3.4983 & 3,304 \\
320 & 4,325 & 2.5051 & 3.6360 & 4,575 \\
440 & 5,525 & 2.6435 & 3.7423 & 5,745 \\
544 & 6,925 & 2.7356 & 3.8404 & 6,686 \\
765 & 8,575 & 2.8837 & 3.9332 & 8,533 \\
1088 & 10,800 & 3.0366 & 4.0334 & 10,978 \\
2000 & 17,700 & 3.3010 & 4.2480 & 16,968 \\
& & & & \\
& & 0.7153 & 1.8685 & 73.87 \\
& & 0.0207 & 0.0559 & \\
& & 0.9950 & 0.0225 & \\
& & 1199.1799 & 6.0000 &
\end{tabular}




\section{Pressure Pump Costs}

$\begin{array}{ccccccc}\begin{array}{c}\text { Capacity } \\ \text { hp }\end{array} & \begin{array}{r}\text { Material } \\ \text { Cost, \$ }\end{array} & \begin{array}{c}\text { Installation } \\ \text { hours }\end{array} & \begin{array}{c}\text { Installation } \\ \text { Cost @ } \$ 25 / \mathrm{hr}\end{array} & \begin{array}{c}\text { Installed } \\ \text { Cost, \$ }\end{array} & \begin{array}{c}\text { Mtl Hand'g } \\ \text { Profit, \$ }\end{array} & \begin{array}{c}\text { Total } \\ \text { Cost, \$ }\end{array} \\ 1.00 & 2335 & 12.30 & 307.50 & 2642.50 & 574.63 & 3217.13 \\ 1.50 & 2365 & 12.80 & 320.00 & 2685.00 & 585.00 & 3270.00 \\ 2.00 & 2440 & 13.30 & 332.50 & 2772.50 & 604.38 & 3376.88 \\ 3.00 & 2550 & 14.50 & 362.50 & 2912.50 & 636.88 & 3549.38 \\ 5.00 & 2752 & 16.00 & 400.00 & 3152.00 & 690.40 & 3842.40 \\ 7.50 & 3025 & 16.90 & 422.50 & 3447.50 & 752.88 & 4200.38\end{array}$

Pressure Pump Costs

$\begin{array}{ccccc}X & Y & \log X & \log Y & Y \text { Calc } \\ 1.00 & 3217.13 & 0.0000 & 3.5075 & 3108.48 \\ 1.50 & 3270.00 & 0.1761 & 3.5145 & 3294.21 \\ 2.00 & 3376.88 & 0.3010 & 3.5285 & 3432.68 \\ 3.00 & 3549.38 & 0.4771 & 3.5502 & 3637.78 \\ 5.00 & 3842.40 & 0.6990 & 3.5846 & 3913.72 \\ 7.50 & 4200.38 & 0.8751 & 3.6233 & 4147.56 \\ 10.00 & 4408.13 & 1.0000 & 3.6443 & 4321.90\end{array}$

$\begin{array}{rrr}0.1431 & 3.4925 & 3108.4798 \\ 0.0117 & 0.0071 & \\ 0.9676 & 0.0106 & \\ 149.5140 & 5.0000 & \end{array}$


Hot Water Storage Tank

\begin{tabular}{|c|c|c|c|c|c|c|}
\hline $\begin{array}{c}\text { Capacity } \\
\text { Gal }\end{array}$ & $\begin{array}{c}\text { Material t } \\
\text { Cost, } \$\end{array}$ & $\begin{array}{l}\text { Installation } \\
\text { hours }\end{array}$ & $\begin{array}{c}\text { Installation } \\
\text { Cost @\$25/hr }\end{array}$ & $\begin{array}{l}\text { Installed } \\
\text { Cost, \$ }\end{array}$ & $\begin{array}{l}\text { Mtl Hand'g } \\
\text { Profit, \$ }\end{array}$ & $\begin{array}{l}\text { Total } \\
\text { Cost, } \$\end{array}$ \\
\hline 225 & 3,540 & & 100 & 3,640 & 372 & 4,012 \\
\hline 460 & 6,190 & & 100 & 6,290 & 637 & 6,927 \\
\hline 740 & 8,400 & & 100 & 8,500 & 858 & 9,358 \\
\hline 940 & 9,730 & & 100 & 9,830 & 991 & 10,821 \\
\hline 1,505 & 12,550 & & 100 & 12,650 & 1,273 & 13,923 \\
\hline 3,815 & 25,200 & & 100 & 25,300 & 2,538 & 27,838 \\
\hline
\end{tabular}

Water Storage Tank Costs

\begin{tabular}{|c|c|c|c|c|}
\hline $\begin{array}{c}X \\
\text { Capacity, } \\
\text { Gallons }\end{array}$ & $\begin{array}{c}Y \\
\text { Cost, S }\end{array}$ & $\begin{array}{c}\log X \\
\log \text { Capacity }\end{array}$ & $\begin{array}{l}\log Y \\
\text { Log Cost }\end{array}$ & $\begin{array}{c}\text { YCalc } \\
\text { Calculated } \\
\text { Cost, } \$\end{array}$ \\
\hline 225 & 4,012 & 2.3522 & 3.6034 & 4,125 \\
\hline 460 & 6,927 & 2.6628 & 3.8405 & 6,658 \\
\hline 740 & 9,358 & 2.8692 & 3.9712 & 9,153 \\
\hline 940 & 10,821 & 2.9731 & 4.0343 & 10,743 \\
\hline 1505 & 13,923 & 3.1775 & 4.1437 & 14,721 \\
\hline \multirow[t]{6}{*}{3815} & 27,838 & 3.5815 & 4.4446 & 27,440 \\
\hline & & 0.6694 & 2.0407 & 109.84 \\
\hline & & 0.0181 & 0.0535 & \\
\hline & & 0.9971 & 0.0171 & \\
\hline & & 1373.4011 & 4.0000 & \\
\hline & & 0.4017 & 0.0012 & \\
\hline
\end{tabular}




\section{Cooling Tower Costs}

Cooling Tower costs are liner (directly proportional) with capacity

$\begin{array}{ccccccc}\begin{array}{c}\text { Capacity } \\ \text { Ton }\end{array} & \begin{array}{c}\text { Material } \\ \text { Cost, } \$\end{array} & \begin{array}{c}\text { Installation } \\ \text { hours }\end{array} & \begin{array}{c}\text { Installation } \\ \text { Cost @ } \$ 25 / h r\end{array} & \begin{array}{c}\text { Installed } \\ \text { Cost, } \$\end{array} & \begin{array}{c}\text { Mt Hand'g } \\ \text { Profit, } \$\end{array} & \begin{array}{c}\text { Total } \\ \text { Cost, \$ }\end{array} \\ 1 & 59 & 0.25 & 6.25 & 65.25 & 7.025 & 72\end{array}$




\section{APPENDIX 2, LIST OF MODEL VARIABLE NAMES}

\author{
Absorption_DelP \\ AC_Thermal_Booster \\ Accumulator_Coefficient \\ Accumulator_Cost \\ Accumulator_Exponent \\ Air_Conditioning \\ Air_conditioning_chiller_capacity_tons \\ Annual_1146_Emission \\ Annual_Emission \\ Annual_Gas_Cost \\ Annual Incentives \\ Annual_Operating_Costs \\ Annual_Power \\ Annual_Power_Costs \\ Annual_Power_Value \\ Annual_Thermal \\ Annual_Thermal_Demand \\ Annual_Thermal_Value \\ Application_Electrical_Demand \\ Application_Thermal_Demand \\ Availability \\ Backup_Gas \\ Backup_Power \\ Boller_Coefficient \\ Boller_Cost \\ Boller_Efficiency \\ Boiler_exponent \\ Boiler_Fuel \\ Boller_NOx \\ Boiler_Output \\ Btu_perTon_Hr \\ CEC_Gas_Forecast \\ Cell_Cost \\ Coll_Cost_Rate \\ Coll_Stack \\ Chiller_Coefilicient \\ Chiller_Cost \\ Chiller_Exponent \\ Chiller_Pump_Capacity_hp \\ Chiller_Pump_Power
}

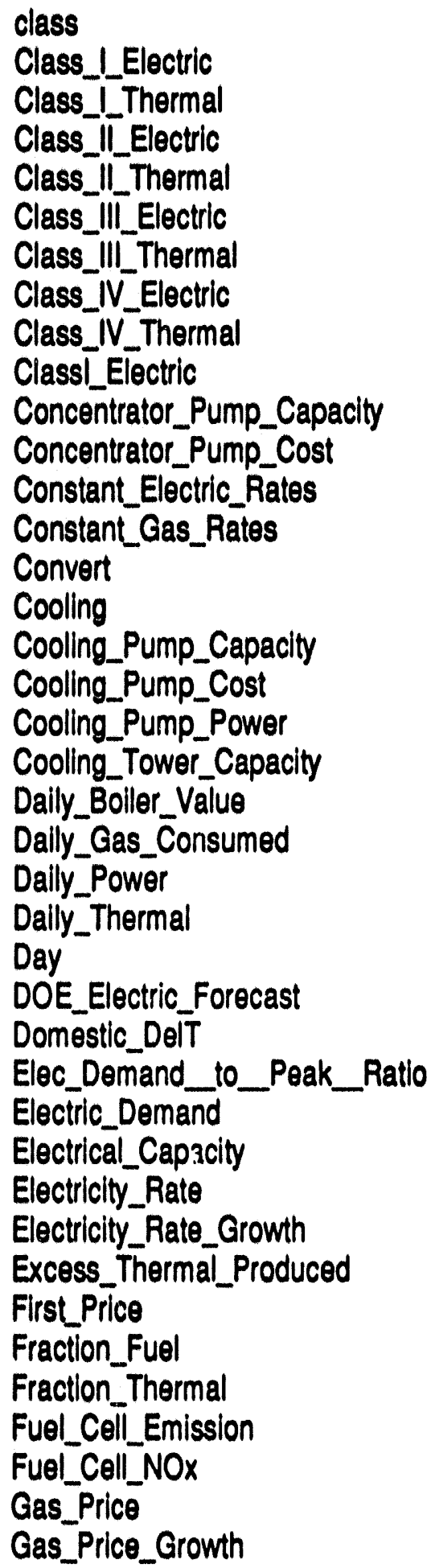




\author{
Gas_Xport \\ Gasrate \\ GRI_Electric_Forecast \\ GRI_Gas_Forecast \\ Grid_Connection \\ Grid_Standby_Connection \\ Growth_Rate \\ Heating \\ Heating_Pump_Capacity \\ Heating_Pump_Cost \\ Heating_Pump_Power \\ Heating_Value \\ Hot_Water_Pump_Power \\ Hot_Water_Pump_Capacity \\ Hrate \\ Industrial_Electricity_Rates \\ Industrial_Off_Peak \\ Industrial_Peak \\ Input_Eloctricity_Rates \\ Input_Off_Peak \\ Input_Peak \\ Installation \\ Interest \\ kWhr_per_hp \\ Lb_per_Gallon \\ Learning \\ Lifo \\ Load_Lovel \\ Loop_DelP \\ Maintenance \\ Makeup_Boller_Capacity \\ Miscollañoous_Equipmant \\ Miscellaneous_Equipment_Costs \\ MTBO \\ NOx_Emission \\ NOX_ERC \\ NOx_Price \\ NOx_UDC \\ $O$ and $M$ \\ Other_Thermal \\ Overhaul \\ Peak_Electrical \\ Peak_Thermal \\ Plant_Capital_Cost
}

PM10_Prico

Population

Print_Area

Pump_Cost_Coefficient

Pump_cost_Exponent

Purchased_Power

Purchased_Power_Cost

Residential_Electricity_Rates

Residential_Off_Peak

Residential_Peak

ROG_Price

Routine

SOx_Price

Space_Cooling_DelT

Space_cooling_pump_capacity_gal_per_min.

Space_Heat_Capacity

Space_Heat_DelT

Summer

Summer

Summer_Boller_Fuel

Summer_Boiler_Thermal

Summer_Boiler_Thermal_Value

Summer_Cell_Gas

Summer_Chiller_Fuel

Summer_Demand

Summer_Gas_Cost

Summer_Gas_Price

Summer_Gas_Purchase

Summer_Power

Summer_Power_Sales

Summer_Power_Value

Summer_Sale_Power

Summer_Thermal

Summer_Thermal_Demand

Summer_Thermal_Value

Thermal_accumulator_tank_capacity_gal.

Thermal_Capacity

Thermal_Demand

Thermal_Demand_to_Peak_Ratio

Thermal_Output_Ratio

Tower_Coefficient

Tower_Cost

Tower_DelT

Tower_Pump_Capacity 
Tower_Pump_Cost

Tower_Pump_Power

UDC_NONOX

UDC_Power

UEG_NOX

UEG_SO $x$

User_Class

User_Input_Electric_Forecast

User_Input_Forecast

User_Input_Gas_Forecast

Volume

Water_Pump_Capacity

Water_Pump_Cost

Winter

Winter_Boller_Fuel

Winter_Boller_Thermal_Value

Winter_Coll_Gas

Winter_Demand

Winter_Gas_Cost

Winter_Gas_Price

Winter_Gas_Purchase

Winter_Natural_Gas_Purchase

Winter_Power

Winter_Power_Sales

Winter_Power_Value

Winter_Sale_Power

Winter_Thermal

Winter_Thermal_Demand

Winter_Thermal_Value

Year 


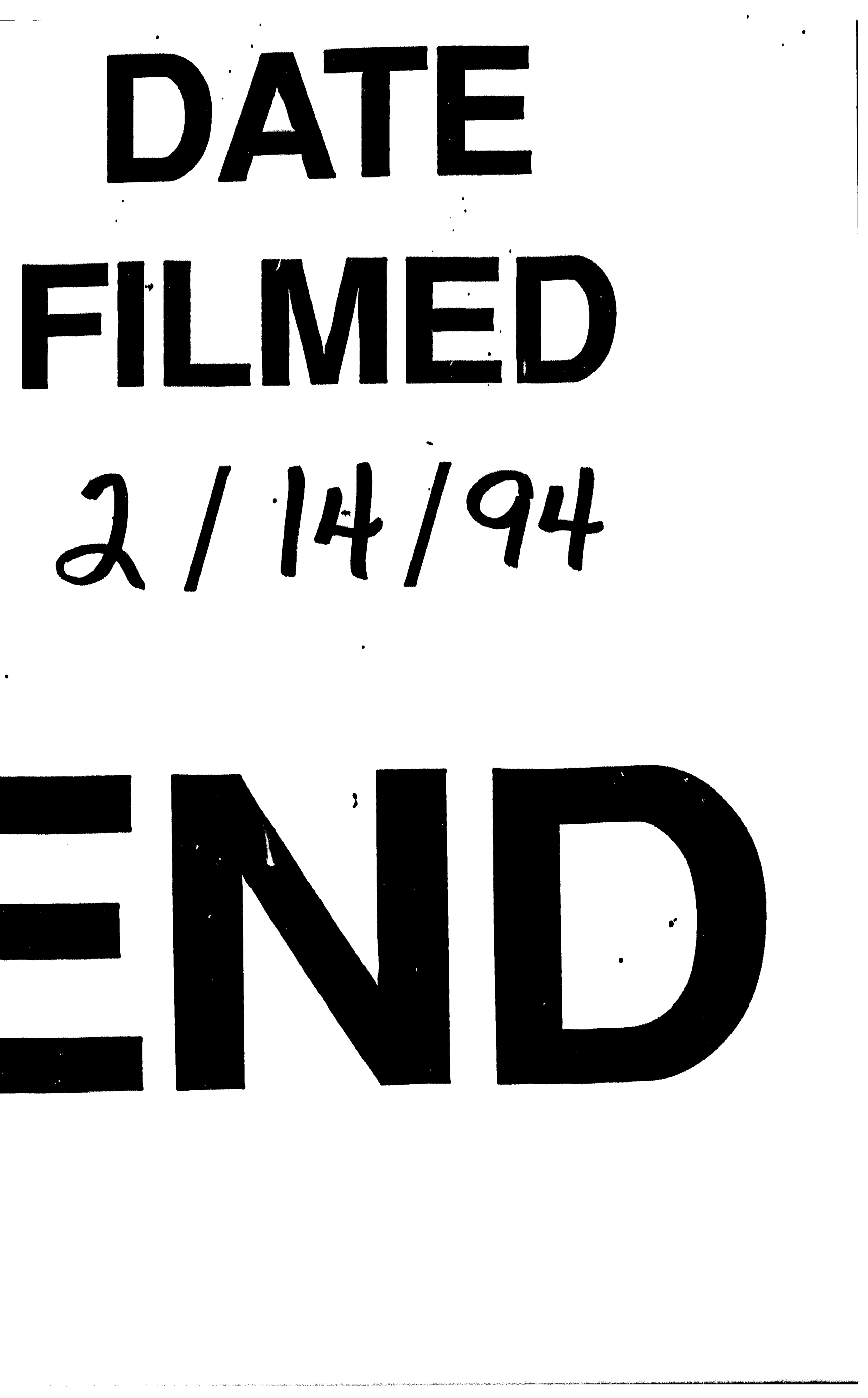


